\title{
Importance of Interlayer Equivalent Pores for Anion Diffusion in Clay-Rich Sedimentary Rocks
}

\author{
Cornelia Wigger*(1) and Luc R. Van Loon* \\ Laboratory for Waste Management, Paul Scherrer Institut, 5232 Villigen PSI, Switzerland \\ Supporting Information
}

ABSTRACT: The anion exclusion behavior in two different clay stones, Opalinus Clay (OPA) and Helvetic Marl (HM), was studied using a well-established experimental throughdiffusion technique. The ionic strength of the pore water was varied between 0.01 and $5 \mathrm{M}$ to evaluate its effect on the diffusion of HTO and ${ }^{36} \mathrm{Cl}^{-}$. The total porosity determined by HTO-diffusion was independent of the ionic strength, while the anion accessible porosity varies with the ionic strength of the pore water. In the case of Opalinus Clay, the anion accessible porosity increases from $3 \%$ at low ionic strength $(0.01 \mathrm{M})$ up to $8.4 \%$ at high ionic strength $(5 \mathrm{M})$, whereas the anion accessible porosity of Helvetic Marl increases from $0.6 \%$

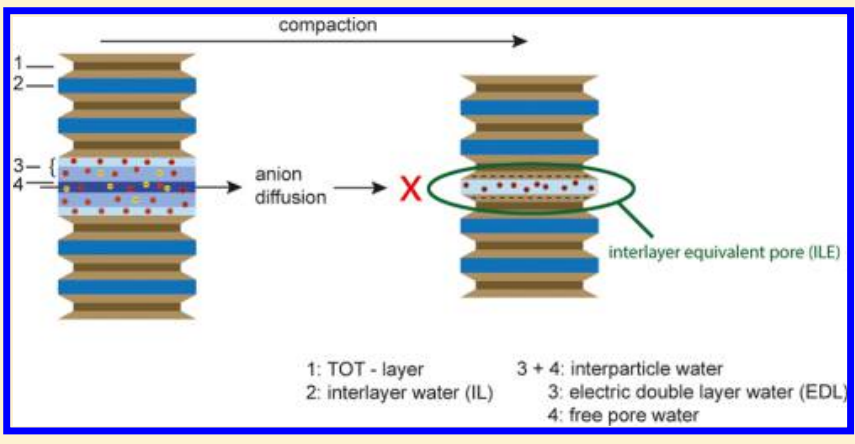
up to only $1.1 \%$. The anion exclusion effect in HM is thus more pronounced than that in OPA, even at high ionic strength. This observation can be correlated to differences in mineralogy and to the fact that HM has a larger fraction of interlayer equivalent pores. Interlayer equivalent pores are small pores in compressed clay stones that are small enough to have, because of overlapping electric double layers, properties similar to those of interlayers and are therefore rather inaccessible for anions.

\section{INTRODUCTION}

The disposal of radioactive waste in argillaceous sedimentary rocks is considered in various countries, e.g., Switzerland, France, Belgium, and Canada. ${ }^{1-4}$ Several advantageous properties of these rocks, such as the low hydraulic conductivity $\left(<10^{-11} \mathrm{~m} / \mathrm{s}\right)$, strong sorption of radionuclides, and slow radionuclide migration dominated by molecular diffusion, ${ }^{5}$ make these rocks ideal candidates for hosting a radioactive waste repository. In the case of argillaceous rocks, the pore volume, pore size distribution, and pore connectivity are dictated by the amount and type of clay minerals building the mineral framework and microstructure of the rock. This is due to the fact that the particle size of clay minerals is much smaller than the grain size of the other composing minerals such as quartz and calcite, the latter having no or only a negligibly small porosity next to the surface. ${ }^{6}$ Connected pores in clay stones are thus mainly associated with the clay matrix ${ }^{7,8}$ and have equivalent diameters in the nanometer range, i.e., clay stones have micropores with a pore diameter $<2 \mathrm{~nm}$ and mesopores with a diameter between 2 and $50 \mathrm{~nm} .{ }^{9,10}$ Besides the pore size, also the surface charge of the pore walls significantly affects ion migration. ${ }^{11-13}$ For neutral and positively charged chemical species having small sizes $(<1$ $\mathrm{nm})$, the whole pore space of a clay rock is available for transport. ${ }^{14,15,6}$ However, anions are repulsed by the negatively charged clay mineral surface. ${ }^{16}$ Hence, only a part of the pore space is available for anion transport, i.e., the anion accessible porosity is less than the total porosity. ${ }^{17-21}$ This effect is wellknown as anion exclusion and has been observed in clayey soils, $^{22,16,23,24}$ in compacted single-clay systems, ${ }^{25}$ and in argillaceous rocks. ${ }^{26,19,27,15}$ Several studies were performed aiming to understand the anion exclusion effect in bentonite, ${ }^{28,29}$ in compacted clay, ${ }^{30}$ and in argillaceous rocks such as Opalinus Clay, ${ }^{3,14,31,12,32}$ Helvetic Marls, ${ }^{33}$ Callovo-Oxfordian argillites and Oxfordian limestones, ${ }^{34,19}$ and Boom Clay. ${ }^{35}$ All these studies show that both the diffusive anion fluxes in these clay formations and the measured transport porosities were smaller compared to those of HTO because of the anion exclusion effect (Figure 1). Although an anion accessible porosity of ca. $50 \% \pm$ $10 \%$ of the total porosity was observed for a majority of claystones, ${ }^{36}$ lower values down to $10 \%$ of the total porosity were also found. ${ }^{15,37}$ A few studies discuss the impact of ionic strength of the pore water on the anion exclusion effect in bentonite ${ }^{29,38,28,17}$ and in clay formations, ${ }^{35,39}$ e.g., Moors ${ }^{35}$ studied the effect of varying ionic strength $(0.016-1 \mathrm{M})$ on the diffusion of $\mathrm{I}^{-}$in Boom Clay and observed a higher accessible porosity with increasing ionic strength. Wittebroodt et al. ${ }^{37}$ studied the diffusion of ${ }^{36} \mathrm{Cl}^{-}$and ${ }^{125} \mathrm{I}^{-}$in Upper Toarcian argillite samples from Tournemire and could also observe a significant effect of varying ionic strength $(0.012-0.12 \mathrm{M})$ on the anion accessible porosity. In addition to the experimental studies, several theorical approaches exist to model the anion porosity in clay rocks. Muurinen et al., ${ }^{40}$ Birgersson and Karnland, ${ }^{41}$ Appelo and Wersin, ${ }^{42}$ and Jougnot et al. ${ }^{43}$ based their analyses on a

Received: July 28, 2016

Revised: January 13, 2017

Accepted: January 15, 2017

Published: January 16, 2017 


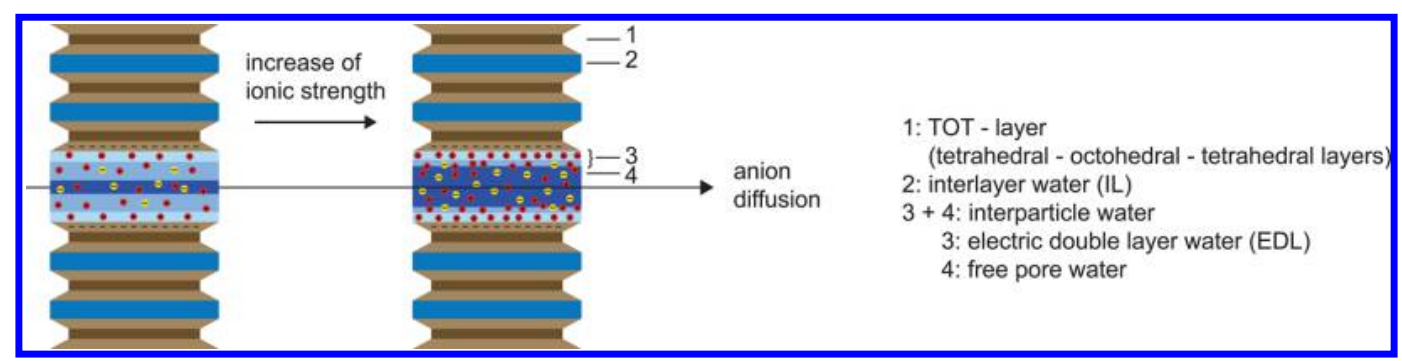

Figure 1. Schematic picture of the pore space of argillaceous rocks and the potential effect of ionic strength on the anion accessible pore space. The total pore space comprises the interlayer water (2) and interparticle pore water ( 3 and 4 ). The interparticle pore water equals the electric double-layer pore water (3) and the free uncharged pore water (4). Anion diffusion takes place mainly in the free pore water. ${ }^{28}$

Donnan approach, while Bourg et al., ${ }^{44}$ Sposito, ${ }^{13}$ Tournassat et al., ${ }^{45}$ and Greathouse et al. ${ }^{46}$ interpreted the anion exclusion porosity in the framework of the Gouy-Chapman theory. The majority of the experimental and modeling studies dealing with compacted bentonites showed that the anion accessible porosity increases with increasing ionic strength. ${ }^{17,28,38,41,47}$ This could be explained by a compression of the electric double layer (EDL) at high ionic strength. The EDL arises from the screening of the negative surface charge of clay minerals by accumulating cations. It consists of a Stern layer, devoid of anions, and a diffuse layer where the concentration of anions is lower than that of cations. $^{48,49}$ At high ionic strength a lower volume of the diffuse layer is necessary to compensate the negative charge on the surface (Figure 1). ${ }^{11}$

In the case of natural argillaceous rocks, systematic studies on the effect of the ionic strength on the anion accessible porosity are scarce, and because of contradictory results it is not clear at all whether clay stones behave in a way similar to that of compacted bentonite. Moreover, the broad range of values for anion accessible porosities (10-60\% of the total porosity) observed for different argillaceous rocks have not been explained properly to date. This prompted us to perform a systematic investigation of the anion accessible porosity in natural clay rocks. The aim of the work is to study the anion diffusion behavior and the anion exclusion effect in clay rocks with different mineral composition in order to better understand the relationship between the ionic strength of the pore water, the mineral composition of the rock, and the anion diffusion in these clay rocks. This will also enable us to better constrain the anion accessible porosity with respect to the estimation of the pore water composition.

\section{MATERIALS AND METHODS}

Samples. Two different clay stone samples were used in this study: Opalinus Clay and Helvetic Marl. The Opalinus Clay (OPA) sample originated from the Schlattingen deep borehole and was taken at a depth of between $-935.14 \mathrm{~m}$ and $-935.45 \mathrm{~m}$. The borehole from Schlattingen is located at a distance of ca. 70 $\mathrm{km}$ north-northwest of the geological siting region Zurich northeast, a potential site for hosting a repository for radioactive waste in Switzerland. ${ }^{50}$ The OPA sample represents a homogeneous clay facies and has a clay content of $69 \%$. The detailed mineral composition, as well as selected sample properties, such as cation exchange capacity, total porosity, and bulk dry density, are given in Table 1 . The second sample used in this investigation is a Helvetic Marl (HM) sample from a borehole in the region Wellenberg at a depth of $-475.86 \mathrm{~m}$. The region Wellenberg was proposed as potential site for a waste repository for low- and intermediate-level waste in Switzerland, ${ }^{50}$ but it was finally disqualified. ${ }^{51}$ Unlike OPA, HM has a lower clay content of only $26 \%$. The detailed properties of the HM sample
Table 1. Mineral Composition and Physico-Chemical Properties of Opalinus Clay and Helvetic Marl Samples Used in This Work

\begin{tabular}{|c|c|c|}
\hline parameter & Opalinus Clay & Helvetic Marl \\
\hline sample & SLA-936.25 & WLB SB4a/v-475.86 \\
\hline grain density $\left(\mathrm{kg} / \mathrm{dm}^{3}\right)$ & $2.70 \pm 0.0023$ & $2.73 \pm 0.0013$ \\
\hline bulk dry density $\left(\mathrm{kg} / \mathrm{dm}^{3}\right)$ & $2.46 \pm 0.029$ & $2.66 \pm 0.027$ \\
\hline total porosity (\%) ${ }^{a}$ & $8.89 \pm 1.18$ & $2.56 \pm 1.04$ \\
\hline $\mathrm{CEC}$ (mequiv/kg sample) ${ }^{b}$ & $105 \pm 0.5$ & $56 \pm 0.2$ \\
\hline mineralogy $(\text { wt } \%)^{c}$ & $31.0 \pm 3$ & $74.0 \pm 3$ \\
\hline calcite & 6.0 & 38 \\
\hline dolomite & $<1$ & 3 \\
\hline plagioclase & 1 & 2 \\
\hline pyrite & $<1$ & 1 \\
\hline quartz & 20 & 25 \\
\hline siderite & 2 & 0 \\
\hline ankerit & $<1$ & 4 \\
\hline K-feldspar & 2 & 1 \\
\hline phyllosilicates (wt \%) & $69 \pm 3$ & $26 \pm 3$ \\
\hline kaolinite & 28.3 & 0.26 \\
\hline chlorite & 7.6 & 10.7 \\
\hline illite & 24.8 & 10.9 \\
\hline illite/smectite & 7.6 & 4.4 \\
\hline
\end{tabular}

${ }^{a}$ Calculated from the grain and bulk dry density. ${ }^{b}$ Measured by the Csmethod. ${ }^{52}{ }^{c} \mathrm{XRD}$ measured with an internal standard $(\mathrm{LiF})$ and peak analyzed. $^{53}$

are also given in Table 1. The comparison of the two samples is interesting because of the significant differences in mineral composition, total porosity, cation exchange capacity, and bulk dry density.

Sample Preparation. The drill cores with a diameter of 0.1 $\mathrm{m}$ were sliced perpendicular to the core axis into pieces with a thickness between 0.005 and $0.007 \mathrm{~m}$. From these slices decagonal samples with a diameter of ca. $0.065 \mathrm{~m}$ were produced. Each polygon was placed into a Plexiglas cylinder with a diameter of $0.1 \mathrm{~m}$ and a height of $0.02 \mathrm{~m}$, and embedded in an epoxy resin (Epofix, Struers $\mathrm{GmbH}$ ). After hardening of the resin, the cylinder was placed on a lathe to remove the resin at the front ends.

Resaturation. The samples were mounted in a diffusion cell described in detail in Van Loon and Mibus. ${ }^{15}$ Each diffusion cell comprised two plates consisting of Ertalyte, an unreinforced polyester based on polyethylene terephthalate (PET-P). Sintered titanium filters were implemented in the plates (diameter $=0.065$ $\mathrm{m}$; thickness $=0.0012 \mathrm{~m}$; pore diameter $=1 \times 10^{-5} \mathrm{~m}$; porosity $=$ $0.1)$. The rock sample was sandwiched between the filters, confined by the plates, and fixed by four bolts (Figure 2). Each plate had two connections for the tubings (inner diameter $=$ 


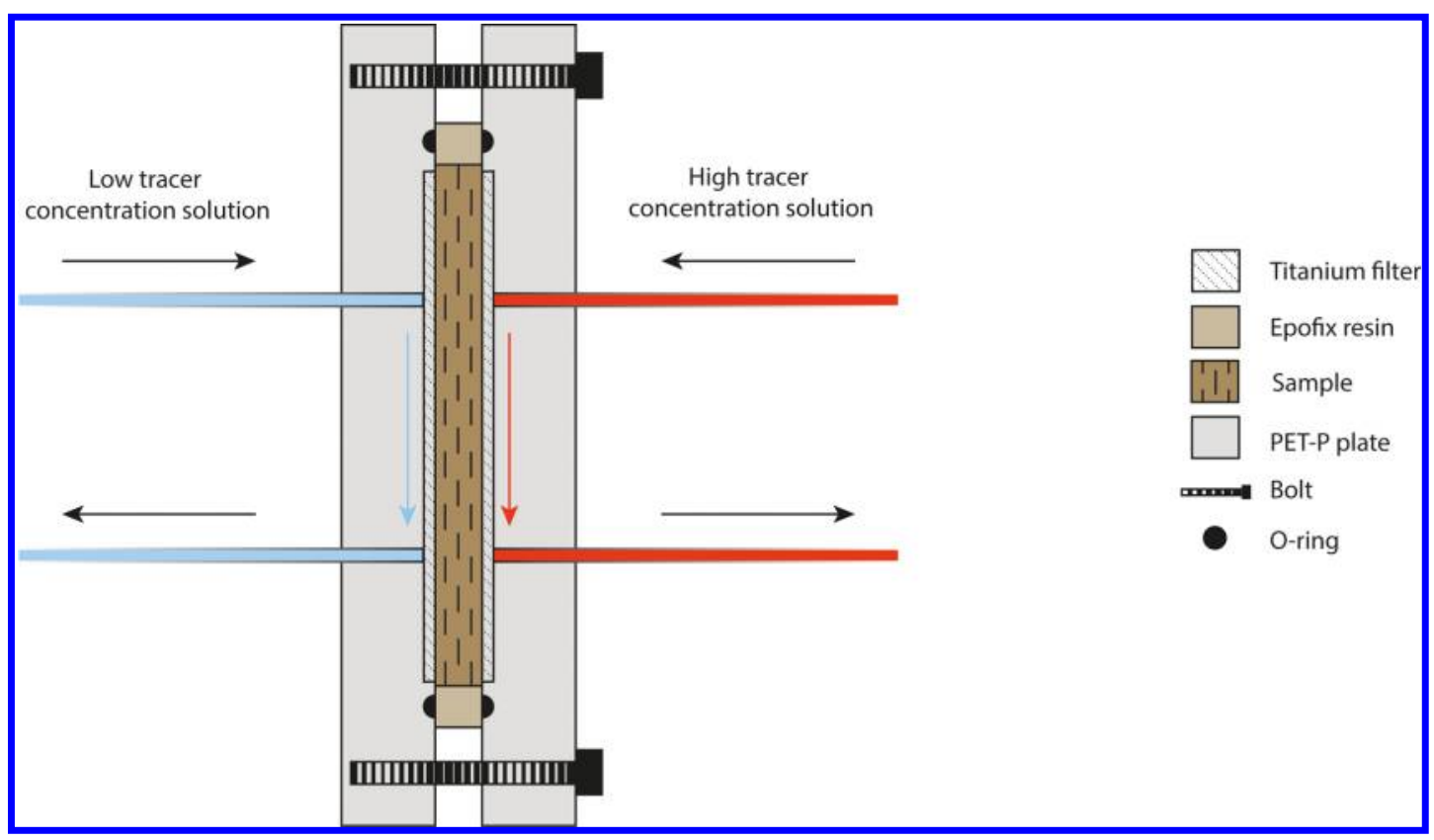

Figure 2. Cross-sectional view of the diffusion cell.

Table 2. Chemical Composition of the Different Pore Water Used in the Diffusion Experiments

\begin{tabular}{|c|c|c|c|c|c|}
\hline \multirow[b]{2}{*}{ element } & \multicolumn{5}{|c|}{ Opalinus Clay } \\
\hline & $0.01 \mathrm{M}$ & $0.1 \mathrm{M}$ & $1 \mathrm{M}$ & $2 \mathrm{M}$ & $5 \mathrm{M}$ \\
\hline $\mathrm{Na}$ & $1.37 \times 10^{-2}$ & $9.99 \times 10^{-2}$ & $1.00 \times 10^{0}$ & $2.00 \times 10^{0}$ & $4.63 \times 10^{0}$ \\
\hline $\mathrm{K}$ & $1.50 \times 10^{-4}$ & $3.07 \times 10^{-4}$ & $5.47 \times 10^{-4}$ & $5.07 \times 10^{-4}$ & $3.85 \times 10^{-4}$ \\
\hline $\mathrm{Ca}$ & $1.96 \times 10^{-4}$ & $1.39 \times 10^{-3}$ & $3.42 \times 10^{-3}$ & $2.94 \times 10^{-3}$ & $8.63 \times 10^{-4}$ \\
\hline $\mathrm{Mg}$ & $6.27 \times 10^{-5}$ & $4.39 \times 10^{-4}$ & $9.95 \times 10^{-4}$ & $8.80 \times 10^{-4}$ & $2.13 \times 10^{-4}$ \\
\hline $\mathrm{Cl}$ & $1.06 \times 10^{-2}$ & $1.05 \times 10^{-1}$ & $1.05 \times 10^{0}$ & $2.09 \times 10^{0}$ & $4.78 \times 10^{0}$ \\
\hline \multirow[t]{2}{*}{$\mathrm{SO}_{4}$} & $2.90 \times 10^{-4}$ & $1.97 \times 10^{-4}$ & $2.05 \times 10^{-4}$ & $1.92 \times 10^{-4}$ & $4.41 \times 10^{-4}$ \\
\hline & \multicolumn{5}{|c|}{ Helvetic Marl } \\
\hline element & $0.01 \mathrm{M}$ & $0.1 \mathrm{M}$ & $1 \mathrm{M}$ & $2 \mathrm{M}$ & $5 \mathrm{M}$ \\
\hline $\mathrm{Na}$ & $1.20 \times 10^{-2}$ & $1.07 \times 10^{-1}$ & $1.01 \times 10^{0}$ & $2.06 \times 10^{0}$ & $4.66 \times 10^{0}$ \\
\hline $\mathrm{K}$ & $3.69 \times 10^{-5}$ & $5.53 \times 10^{-5}$ & $1.05 \times 10^{-4}$ & $8.20 \times 10^{-5}$ & $8.87 \times 10^{-5}$ \\
\hline $\mathrm{Ca}$ & $3.46 \times 10^{-4}$ & $8.18 \times 10^{-4}$ & $1.45 \times 10^{-3}$ & $1.61 \times 10^{-3}$ & $7.38 \times 10^{-4}$ \\
\hline $\mathrm{Mg}$ & $1.71 \times 10^{-4}$ & $4.29 \times 10^{-4}$ & $5.08 \times 10^{-4}$ & $5.26 \times 10^{-4}$ & $1.61 \times 10^{-4}$ \\
\hline $\mathrm{Cl}$ & $1.06 \times 10^{-2}$ & $1.07 \times 10^{-1}$ & $1.05 \times 10^{0}$ & $2.11 \times 10^{0}$ & $4.88 \times 10^{0}$ \\
\hline $\mathrm{SO}_{4}$ & $2.35 \times 10^{-4}$ & $1.62 \times 10^{-4}$ & $7.44 \times 10^{-5}$ & $8.20 \times 10^{-5}$ & $8.55 \times 10^{-4}$ \\
\hline
\end{tabular}

$0.001 \mathrm{~m}$ ). A 24-channel peristaltic pump (IPC, Ismatec, Idex, United States) pumped the solutions through the tubings toward the filters. The clay samples were saturated with solutions with different compositions ranging from 0.01 to $5 \mathrm{M} \mathrm{NaCl}$. The saturation was conducted in the same setup as the diffusion experiments by circulating a $\mathrm{NaCl}$-solution through the samples. For every clay rock, five different experiments were started at the same time: $0.01 \mathrm{M} \mathrm{NaCl}, 0.1 \mathrm{M} \mathrm{NaCl}, 1 \mathrm{M} \mathrm{NaCl}, 2 \mathrm{M} \mathrm{NaCl}$, and $5 \mathrm{M} \mathrm{NaCl}$. The change in ionic composition of the circulating solution $\left(\mathrm{Ca}, \mathrm{Mg}, \mathrm{Na}, \mathrm{K}, \mathrm{Cl}, \mathrm{SO}_{4}\right.$ ) was monitored by ion chromatography (IC) measurements (ICS5000+, ThermoFischer) every second week. After four months, the composition of the pore water solution was found to be stable and chemically stationary conditions between the $\mathrm{NaCl}$ solutions and the rock sample were reached.

Through-Diffusion. After stationary conditions were reached, through-diffusion experiments with tritiated water (HTO) and chloride $\left({ }^{36} \mathrm{Cl}^{-}\right)$were performed for assessing the total porosity (HTO) and the anion accessible porosity $\left({ }^{36} \mathrm{Cl}^{-}\right)$ for samples equilibrated with pore waters of different composition ranging from 0.01 to $5 \mathrm{M} \mathrm{NaCl}$ (Table 2). All diffusion experiments were performed perpendicular to the bedding plane of the samples.

One side of the sample was contacted by $100 \mathrm{~mL}$ of a circulating solution containing the radionuclide of interest $\left(\right.$ HTO or ${ }^{36} \mathrm{Cl}^{-}$). The other side was contacted by $20 \mathrm{~mL}$ of an identical circulating solution without radiotracer.

The solution in the low-concentration reservoir was regularly replaced by a fresh solution to keep the concentration of radiotracer low, i.e., close to zero. The diffusion cells were kept at a constant temperature of $25 \pm 1{ }^{\circ} \mathrm{C}$. The activities of the radiotracers were measured by liquid scintillation counting as explained in detail in Van Loon et al. ${ }^{14}$ From the total diffused mass, both the capacity factor and the effective diffusion coefficient were calculated. Details of the data processing are described in detail in Van Loon et al. ${ }^{14}$ 
Table 3. Summary of Effective Diffusion Coefficients $\left(D_{\mathrm{e}}\right)$ and Porosity Values $(\eta)$ Obtained for $\mathrm{HTO}$ and ${ }^{36} \mathrm{Cl}^{-}$in Diffusion Experiments on Opalinus Clay and Helvetic Marl

\begin{tabular}{|c|c|c|c|c|}
\hline \multirow[b]{3}{*}{$I(\mathrm{M})$} & \multicolumn{4}{|c|}{ Opalinus Clay } \\
\hline & \multicolumn{2}{|c|}{ HTO } & \multicolumn{2}{|c|}{${ }^{36} \mathrm{Cl}^{-}$} \\
\hline & $D_{\mathrm{e}}\left(\mathrm{m}^{2} / \mathrm{s}\right)$ & $\eta(-)$ & $D_{\mathrm{e}}\left(\mathrm{m}^{2} / \mathrm{s}\right)$ & $\eta(-)$ \\
\hline 0.01 & $(1.02 \pm 0.02) \times 10^{-11}$ & $0.120 \pm 0.003$ & $(6.28 \pm 0.26) \times 10^{-13}$ & $0.030 \pm 0.005$ \\
\hline 0.1 & $(8.88 \pm 0.02) \times 10^{-12}$ & $0.122 \pm 0.003$ & $(1.23 \pm 0.07) \times 10^{-12}$ & $0.043 \pm 0.006$ \\
\hline 1 & $(1.12 \pm 0.02) \times 10^{-11}$ & $0.114 \pm 0.003$ & $(2.25 \pm 0.14) \times 10^{-12}$ & $0.069 \pm 0.009$ \\
\hline 2 & $(7.28 \pm 0.02) \times 10^{-12}$ & $0.118 \pm 0.003$ & $(2.01 \pm 0.11) \times 10^{-12}$ & $0.074 \pm 0.007$ \\
\hline \multirow[t]{4}{*}{5} & $(6.48 \pm 0.11) \times 10^{-12}$ & $0.150 \pm 0.003$ & $(1.92 \pm 0.01) \times 10^{-12}$ & $0.084 \pm 0.010$ \\
\hline & \multicolumn{4}{|c|}{ Helvetic Marl } \\
\hline & \multicolumn{2}{|c|}{ HTO } & \multicolumn{2}{|c|}{${ }^{36} \mathrm{Cl}^{-}$} \\
\hline & $D_{\mathrm{e}}\left(\mathrm{m}^{2} / \mathrm{s}\right)$ & $\eta(-)$ & $D_{\mathrm{e}}\left(\mathrm{m}^{2} / \mathrm{s}\right)$ & $\eta(-)$ \\
\hline 0.01 & $(1.48 \pm 0.02) \times 10^{-12}$ & $0.026 \pm 0.002$ & $(7.07 \pm 0.23) \times 10^{-14}$ & $0.0055 \pm 0.0006$ \\
\hline 0.1 & $(1.14 \pm 0.02) \times 10^{-12}$ & $0.030 \pm 0.002$ & $(8.69 \pm 0.20) \times 10^{-14}$ & $0.0078 \pm 0.0009$ \\
\hline 1 & $(1.06 \pm 0.02) \times 10^{-12}$ & $0.030 \pm 0.002$ & $(1.22 \pm 0.04) \times 10^{-13}$ & $0.0085 \pm 0.0006$ \\
\hline 2 & $(1.05 \pm 0.02) \times 10^{-12}$ & $0.029 \pm 0.003$ & $(2.15 \pm 0.04) \times 10^{-13}$ & $0.0078 \pm 0.0006$ \\
\hline 5 & $(7.98 \pm 0.02) \times 10^{-13}$ & $0.031 \pm 0.003$ & $(1.68 \pm 0.05) \times 10^{-13}$ & $0.0110 \pm 0.0018$ \\
\hline
\end{tabular}

\section{RESULTS AND DISCUSSION}

Table 3 gives an overview of the diffusion parameters (effective diffusion coefficient, $D_{\mathrm{e}}$, and transport accessible porosity, $\eta$ ) measured in this study. It is recognizable that the effective diffusion coefficient of HTO decreases with ionic strength in both samples. This decrease of the effective diffusion coefficient can not be observed for experiments with ${ }^{36} \mathrm{Cl}^{-}$. According to the Stokes-Einstein relation, the diffusion coefficient $\left(D_{\mathrm{w}, i}\right)$ of a species $i$ in an aqueous solution is related to the reciprocal dynamic viscosity $(\vartheta)$ of the solution $\left(\mathrm{N} \mathrm{s} \mathrm{m}^{-2}\right)$ :

$$
D_{\mathrm{w}, i}=\frac{k_{\mathrm{B}} T}{6 \pi \vartheta r_{i}}
$$

where $k_{\mathrm{B}}$ is the Boltzmann constant $\left(\mathrm{J} \mathrm{K}^{-1}\right), T$ the temperature $(K)$, and $r_{i}$ the hydrodynamic radius of species $i(\mathrm{~m})$.

The effective diffusion coefficient $\left(D_{\mathrm{e}, i}\right)$ of species $i$ in a porous medium with porosity $\eta$ is defined by

$$
D_{\mathrm{e}, i}=\frac{1}{G} \eta D_{\mathrm{w}, i}
$$

where $G$ is the geometric factor $(-)$. Combining eqs 1 and 2 results in

$$
D_{\mathrm{e}, i}=\frac{\eta k_{\mathrm{B}} T}{6 G \pi \vartheta r_{i}}
$$

It is clear from eq 3 that the effective diffusion coefficient decreases with increasing viscosity of the solution, as long as the other parameters, namely the transport porosity and the geometric factor, remain constant. In the case of HTO, the transport porosity stays constant. Other parameters are assumed constant, such as those sensitive to changes in ionic strength, e.g., osmotic and crystalline swelling of clay minerals, ${ }^{54,55}$ that could impact the geometrical factor. Hence, the decreasing effective diffusion coefficient of HTO can be qualitatively explained by the increase of the solution viscosity with increasing ionic strength. ${ }^{56}$ Unlike HTO, the effective diffusion coefficient of ${ }^{36} \mathrm{Cl}^{-}$increases with ionic strength $(I)$ up to a value of ca. $1 \mathrm{M}$. For an ionic strength $>1 \mathrm{M}$, the effective diffusion coefficient decreases again. Two simultaneous processes have to be considered here. In the case of ${ }^{36} \mathrm{Cl}^{-}$diffusion, the transport porosity increases with increasing ionic strength. As can be concluded from Archie's law, the effective diffusion coefficient increases with increasing porosity. ${ }^{15,39}$ The increase of the solution viscosity at higher ionic strength, however, results in a decrease of the effective diffusion coefficient. At relative low ionic strength $(I<1 \mathrm{M})$, the increase of the effective diffusion coefficient due to an increase in transport porosity is greater than the decrease caused by the change in viscosity. The overall effect is thus an increase of the effective diffusion coefficient. For an ionic strength $>1 \mathrm{M}$, the effect of the increase in viscosity of the medium is significantly greater than the change of the accessible porosity, resulting in an overall decrease of the effective diffusion coefficient. ${ }^{57}$

The total porosity was derived from diffusion experiments with tritiated water (HTO). Tritiated water is an uncharged species and is not repulsed by the negative charge of the clay mineral surfaces. Hence, the whole porosity of the rock samples is assumed to be accessible for HTO. The mean values are $\eta=$ $0.125 \pm 0.015$ and $\eta=0.029 \pm 0.002$ for OPA and HM, respectively. These values are in good agreement with earlier published values on similar samples. ${ }^{15,38}$ It can further be observed from the HTO experiments that the total porosity does not depend on the ionic strength of the pore water. This is in agreement with earlier observations on compacted bentonite ${ }^{28}$ and on compacted illite and montmorillonite. ${ }^{25}$

The total porosity values for both samples obtained by HTOdiffusion are larger than the porosity values calculated from density values (Table 1 ) by the following equation:

$$
\eta_{\mathrm{tot}}=1-\frac{\rho_{\mathrm{b}}}{\rho_{\mathrm{g}}}
$$

where $\eta_{\text {tot }}$ is the total porosity, $\rho_{\mathrm{b}}$ the bulk dry density, and $\rho_{\mathrm{g}}$ the grain density. It is assumed that during the preparation of the samples for the density measurements a shrinkage of the samples took place, due to the crushing, grinding, and drying of the samples. On the other hand, an increase of the total porosity obtained from HTO-diffusion experiments could occur during the resaturation process of the samples. Imprints in the titanium filter do confirm this swelling effect. Because the anion accessible porosity is obtained by diffusion experiments, it is compared to the total porosity measured by HTO-diffusion and not by the total porosity calculated with density values in this work.

The anion accessible porosity was estimated from the diffusion experiments with ${ }^{36} \mathrm{Cl}^{-}$. From Table 3 it can be seen that the 


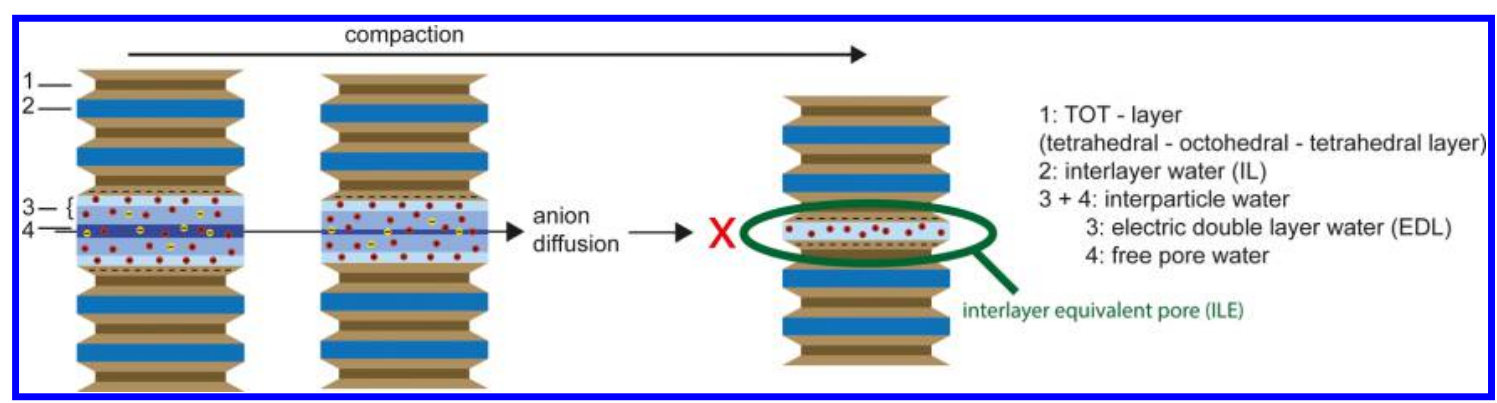

Figure 3. Schematic presentation of the potential formation of interlayer equivalent pores (ILE) in clay rocks and its influence on anion diffusion. ILE pores are assumed not to be accessible for anions.

anion accessible porosity is smaller than the total porosity and depends on the ionic strength of the pore solution, i.e., the anion accessible porosity increases with increasing ionic strength. The resulting accessible anion porosities, given as a fraction of the total porosity, are shown in Figure 4. Between an ionic strength of 0.01 and $1 \mathrm{M}$ the anion accessible porosity increases with increasing ionic strength for OPA as well as for HM. The anion accessible porosity values level off at an ionic strength greater than $1 \mathrm{M}$ for both materials. It can be expected that at this point the electrical double layer is almost completely suppressed and increases less strongly with higher values of ionic strength. ${ }^{57}$

With respect to the total porosity, the anion exclusion effect in Helvetic Marl is larger than the anion exclusion effect in Opalinus Clay (Figure 4). This fact can partially be explained by the different mineralogy of the samples. However, before this discrepancy is analyzed, it has to be known that several studies ${ }^{6-8}$ showed that the porosity of both samples is mainly associated with the clay matrix and that diffusion processes thus mainly take place in the clay fraction and not in the whole rock. Consequently, the observed differences in anion accessible porosity values for a same ionic strength in the two types of samples may be attributed to differences in clay mineralogy but not to the differences in clay content of the samples. Therefore, the total absolute clay amount is sparsely relevant for the analysis. Hence, the authors consider only relative values of the differences in clay mineralogy, e.g., relative amount of charged and uncharged clay minerals. A fraction of the clay minerals, such as illite and illite/smectite mixed layers, have negatively charged surfaces. Anions are repulsed by this negative charge and thus excluded from the charged pores. Kaolinite and chlorite are almost uncharged clay minerals and do not significantly impact the anion accessible porosity. Helvetic Marl has slightly more charged clay minerals (59\% of the clay minerals) than Opalinus Clay; hence, the anion exclusion effect is expected to be larger than in the case of OPA that has only $47 \%$ charged clay minerals. Nevertheless, such a small variance in mineralogy can not explain the large difference of the anion exclusion effect between the two samples.

Another explanation could be the fact that the bulk dry densities of the two materials are different. Other studies indicate that the diffusive properties are highly dependent on the clay partial density. ${ }^{47,59}$ For this reason, a proper normalization of the data is needed. The authors calculated the clay partial density, $\rho_{\text {b,clay, }}$ by the relation

$$
\rho_{\mathrm{b}, \text { clay }}=\frac{f_{\text {clay }} \rho_{\mathrm{b}}}{1-\frac{\left(1-f_{\text {clay }}\right) \rho_{\mathrm{b}}}{\rho_{\text {other }}}}
$$

where $f_{\text {clay }}$ is the fraction of clay ( 0.69 for OPA and 0.26 for HM), $\rho_{\mathrm{b}}$ the bulk dry density $\left(2.46 \mathrm{~kg} / \mathrm{dm}^{3}\right.$ for OPA and $2.66 \mathrm{~kg} / \mathrm{dm}^{3}$ for $\mathrm{HM})$, and $\rho_{\text {other }}$ the average density of nonclay minerals in the solid $\left(2.78 \mathrm{~kg} / \mathrm{dm}^{3}\right.$ for OPA and $2.74 \mathrm{~kg} / \mathrm{dm}^{3}$ for HM based on the calculated data from the mineralogy and density $\left.{ }^{60}\right)$. The $\rho_{\text {b,clay }}$ values for the two samples vary less than the total bulk dry densities, but they still differ significantly: $\rho_{\text {bulk,clay,OPA }}=2.34 \mathrm{~kg} /$ $\mathrm{dm}^{3}$ and $\rho_{\text {bulk,clay,HM }}=2.46 \mathrm{~kg} / \mathrm{dm}^{3}$. A larger bulk density and particularly a larger bulk density in the pore space hosting fraction, i.e., the clay fraction, can lead to interlayer equivalent pores (ILE). Interlayer equivalent pores are small pores in compressed clay stones that are small enough to have properties similar to those of interlayers in clays ${ }^{47}$ and are therefore assumed to be inaccessible for anions. ${ }^{48,49}$ ILE pores are the result of the high degree of compaction typical for clay rocks, as illustrated in Figure 3. The larger the compaction, the larger the expected interlayer equivalent porosity $\left(\eta_{\text {ILE }}\right)$. Because Helvetic Marl has a greater bulk density and also a greater normalized bulk density than Opalinus Clay, it is expected that HM has an ILE porosity that is greater than that of OPA. Because interlayer equivalent pores have properties that are identical to those of "real" interlayer pores (IL), they are rather inaccessible for anions, independent of the ionic strength. This might thus explain the different anion exclusion effect of the two samples at high ionic strength in addition to the different mineralogy.

Data Modeling. Clays have negatively charged surfaces, which leads to partial exclusion of anions from surface regions. Different concepts exist to describe such features, e.g., GouyChapman (GC) model based on the Poisson-Boltzmann equation; ${ }^{24,16,61}$ the modified Gouy-Chapman (MGC) model which is coupled with microstructure information; ${ }^{62}$ and the Donnan model, ${ }^{63}$ where the pore space contains an excess of counterions and a deficit of co-ions that balance the surface charge and at the same time are in equilibrium with a charge-free external solution. Compared to other models, only a few parameters are required and advantageously no structural information is needed for the Donnan approach. Given the fact that the pore space of clay rocks in this study is poorly characterized in terms of pore size distribution and pore shape, and no relevant structural information is available, the Donnan approach was selected to describe the anion exclusion behavior.

In a first step, the data were fitted using a Donnan approach model as described in Birgersson and Karnland. ${ }^{41}$ According to Birgersson and Karnland, the whole pore space of the sample is assumed to be a Donnan space. The anion exclusion porosity, $\eta_{\text {an }}$, is calculated by

$$
\eta_{\mathrm{an}}=\eta_{\mathrm{tot}} \cdot \Xi
$$


Table 4. Parameters Used for Modelling the Anion Accessible OPA and HM as a Function of Ionic Strength

\begin{tabular}{|c|c|c|c|c|}
\hline & & & OPA & $\mathrm{HM}$ \\
\hline total porosity & $\eta_{\text {tot }}$ & {$[-]$} & 0.12 & 0.03 \\
\hline free porosity & $\eta_{\text {free }}$ & {$[-]$} & 0.030 & 0.0055 \\
\hline Stern layer porosity & $\eta_{\text {Stern }}$ & {$[-]$} & $5.85 \times 10^{-12}$ & $6.12 \times 10^{-12}$ \\
\hline interlayer porosity & $\eta_{\mathrm{IL}}$ & {$[-]$} & 0.005 & 0.002 \\
\hline interlayer equivalent porosity & $\eta_{\mathrm{ILE}}$ & {$[-]$} & 0.037 & 0.019 \\
\hline cation exchange capacity, total & $\mathrm{CEC}_{\text {tot }}$ & {$[$ equiv $/ \mathrm{kg}]$} & 0.105 & 0.056 \\
\hline cation exchange capacity, Stern & $\mathrm{CEC}_{\text {Stern }}$ & {$[$ equiv $/ \mathrm{kg}]$} & 0.058 & 0.031 \\
\hline cation exchange capacity, IL & $\mathrm{CEC}_{\mathrm{IL}}$ & {$[$ equiv $/ \mathrm{kg}]$} & 0.008 & 0.004 \\
\hline cation exchange capacity, ILE & $\mathrm{CEC}_{\mathrm{ILE}}$ & {$[$ equiv $/ \mathrm{kg}]$} & 0.028 & 0.016 \\
\hline density of water & $\rho_{\mathrm{w}}$ & {$\left[\mathrm{kg} / \mathrm{m}^{3}\right]$} & 1000 & 1000 \\
\hline amount of equivalents per mole $(\mathrm{Na})$ & $z_{\mathrm{Na}}$ & {$[$ equiv $/ \mathrm{mol}]$} & 1 & 1 \\
\hline mass solid substance & $m_{\mathrm{s}}$ & {$[\mathrm{kg}]$} & 2.460 & 2.660 \\
\hline mass water, total & $m_{\mathrm{w}, \mathrm{tot}}$ & {$[\mathrm{kg}]$} & 0.120 & 0.030 \\
\hline mass water, tot-free & $m_{\mathrm{w}, \text { tot-free }}$ & {$[\mathrm{kg}]$} & 0.116 & 0.030 \\
\hline mass water, tot-free-Stern & $m_{\mathrm{w}, \text { tot-free-Stern }}$ & {$[\mathrm{kg}]$} & 0.116 & 0.030 \\
\hline mass water, tot-free-Stern-IL & $m_{\mathrm{w}, \text { tot-free-Stern-IL }}$ & {$[\mathrm{kg}]$} & 0.116 & 0.030 \\
\hline mass water, tot-free-Stern-IL-ILE & $m_{\mathrm{w}, \text { tot-free-Stern-IL-ILE }}$ & {$[\mathrm{kg}]$} & 0.111 & 0.029 \\
\hline dry density solid & $\rho_{\mathrm{b}}$ & {$\left[\mathrm{kg} / \mathrm{m}^{3}\right]$} & 2.460 & 2.660 \\
\hline Donnan-pore space total & $\eta_{\mathrm{D}}$ & {$[-]$} & 0.120 & 0.030 \\
\hline Donnan-pore space, free & $\eta_{\mathrm{D}, \text { free }}$ & {$[-]$} & 0.090 & 0.025 \\
\hline Donnan-pore space, free-Stern & $\eta_{\mathrm{D}, \text { free-Stern }}$ & {$[-]$} & 0.090 & 0.024 \\
\hline Donnan-pore space, free-Stern-IL & $\eta_{\mathrm{D}, \text { free-Stern-IL }}$ & {$[-]$} & 0.085 & 0.022 \\
\hline Donnan-pore space,free-Stern-IL-ILE & $\eta_{\mathrm{D}, \text { free-Stern-IL-ILE }}$ & {$[-]$} & 0.049 & 0.003 \\
\hline material specific parameter, total & $\Omega_{\text {tot }}$ & {$\left[\mathrm{mol} / \mathrm{m}^{3}\right]$} & 105 & 56 \\
\hline material specific parameter, Stern & $\Omega_{\text {tot-Stern }}$ & {$\left[\mathrm{mol} / \mathrm{m}^{3}\right]$} & 47.25 & 25.20 \\
\hline material specific parameter, IL & $\Omega_{\text {tot-Stern-IL }}$ & {$\left[\mathrm{mol} / \mathrm{m}^{3}\right]$} & 38.98 & 21.28 \\
\hline material specific parameter, ILE & $\Omega_{\text {tot-Stern-IL-ILE }}$ & {$\left[\mathrm{mol} / \mathrm{m}^{3}\right]$} & 11.48 & 5.28 \\
\hline water ratio, total & $w_{\text {tot }}$ & {$[-]$} & 0.049 & 0.011 \\
\hline water ratio, free & $w_{\text {tot-free }}$ & {$[-]$} & 0.047 & 0.011 \\
\hline water ratio, Stern & $w_{\text {tot-free-Stern }}$ & {$[-]$} & 0.047 & 0.011 \\
\hline water ratio, $\mathrm{IL}$ & $w_{\text {tot-free-Stern-IL }}$ & {$[-]$} & 0.047 & 0.011 \\
\hline water ratio, ILE & $w_{\text {tot-free-Stern-IL-ILE }}$ & {$[-]$} & 0.045 & 0.011 \\
\hline activity coefficient factor & $\Gamma_{1}$ & {$[-]$} & 1 & 1 \\
\hline
\end{tabular}

where $\eta_{\text {tot }}$ represents the total porosity and $\Xi$ is the ion equilibrium coefficient, which is defined as

$$
\Xi=-\frac{\Omega}{2 w C}+\sqrt{\frac{\Omega^{2}}{4 w^{2} C^{2}}+\Gamma_{1}}
$$

where $C$ is the anion concentration $(\mathrm{mM}), \Gamma_{1}$ an activity coefficient factor, and $w$ the water ratio, given by

$$
w=\frac{m_{\mathrm{w}}}{m_{\mathrm{s}}}
$$

with $m_{\mathrm{w}}$ and $m_{\mathrm{s}}$ the mass of water and solid substance, respectively, and $\Omega$ is a material-specific parameter (equiv $/ \mathrm{kg}$ ) defined as

$$
\Omega=\frac{\mathrm{CEC} \cdot \rho_{\mathrm{w}}}{z}
$$

where CEC represents the cation exchange capacity (equiv/ $\mathrm{kg}$ ); $\rho_{\mathrm{w}}$ is the density of water $\left(\mathrm{kg} / \mathrm{m}^{3}\right)$, and $z$ denotes the amount of equivalents per mole (equiv/mol), which is 1 equiv/mol in the case of monovalent counterions.

The parameter values used to fit the experimental data by the Donnan approach of Birgersson and Karnland ${ }^{41}$ are given in Table 4. It can be seen from Figure 4 that this model concept does not describe the experimental results. The modeled anion accessible porosity reaches zero at an ionic strength lower than
0.1 M, where the experimental data clearly shows a significant anion accessible porosity for both OPA and HM. Moreover, at high ionic strength the model predicts an anion accessible porosity reaching the total porosity, whereas the data clearly shows a significant exclusion. The reason for this discrepancy between model and experimental data could be that the model of Birgersson and Karnland ${ }^{41}$ is based on a Na-montmorillonite mainly consisting of smectites, i.e., charged clay minerals. However, Opalinus Clay and Helvetic Marl have a substantial amount of almost uncharged clay minerals such as kaolinite and chloride (Table 1). That implies that a part of the pore space might be permanent uncharged and is not affected by the solution composition (ionic strength). For this reason, a free uncharged pore space, $\eta_{\text {free, }}$ was introduced for both samples based on the experimental data at $0.01 \mathrm{M}$, i.e., for OPA $\eta_{\text {free }}=0.03$ and for $\mathrm{HM} \eta_{\text {free }}=0.0055$. The anion accessible porosity can be calculated with the free pore space by ${ }^{47}$

$$
\eta_{\mathrm{an}}=\eta_{\text {free }}+\eta_{\mathrm{D}, \text { free }} \cdot \Xi_{\mathrm{D} \text {,free }}
$$

where $\eta_{\mathrm{D} \text {,free }}=\eta_{\text {tot }}-\eta_{\text {free }}$ is the adapted Donnan pore space and the ion equilibrium coefficient $\Xi_{\mathrm{D} \text {,free }}$ is calculated with the adapted parameters (Table 4 ). The resulting modeled curve shows a better fit than the Donnan approach from Birgersson and Karnland, ${ }^{41}$ but unlike the experimental data, the curve is not leveling out at an ionic strength greater than $1 \mathrm{M}$. 

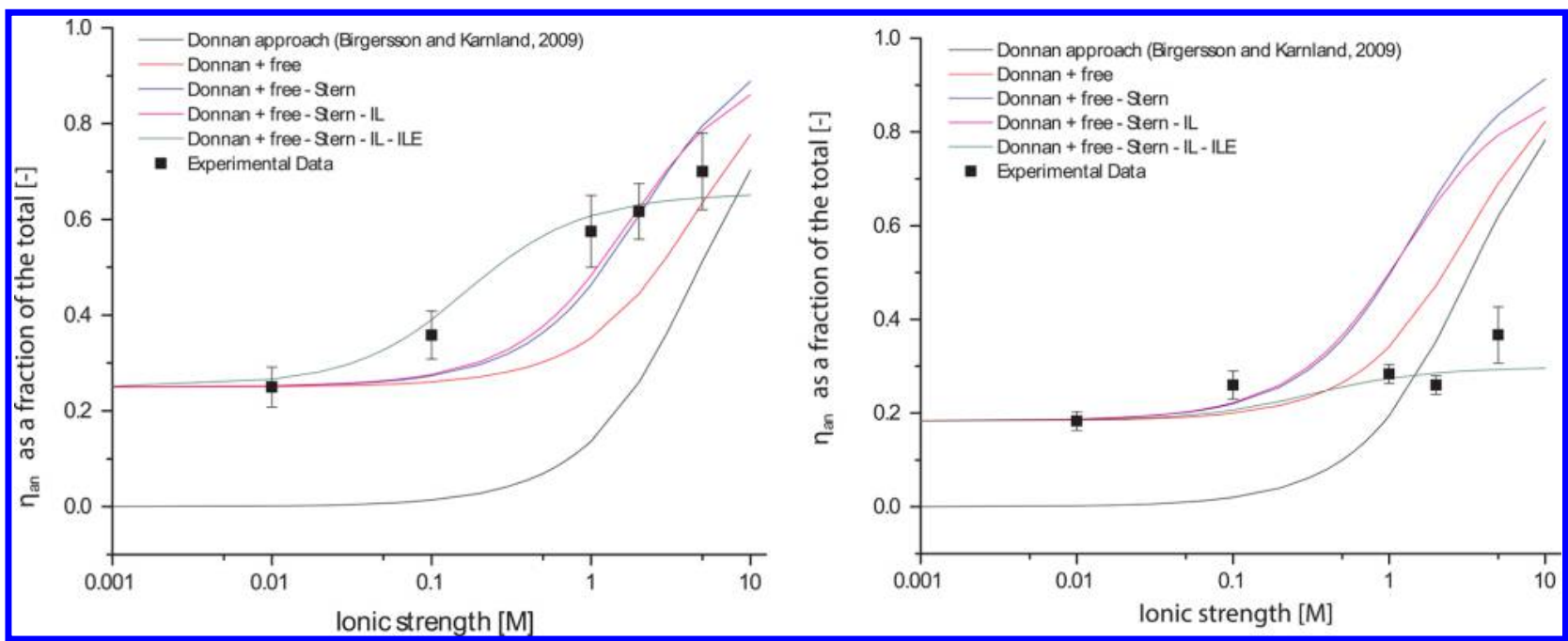

Figure 4. Dependence of the anion accessible porosity on the ionic strength of the pore solution for Opalinus Clay (left) and Helvetic Marl (right). Symbols represent experimental data; solid lines are fitting curves calculated based on a Donnan approach of Birgersson and Karnland (2009) ${ }^{41}$ using the parameters listed in Table 4.

The above calculations were performed considering that the whole surface charge is compensated in the diffuse layer, respectively the Donnan space. However, a part of this charge can be compensated in the Stern layer, which is the first hydration layer at the charged mineral surface and not accessible for anions. ${ }^{47}$ The Stern layer charge for Opalinus Clay was estimated by Appelo et al. ${ }^{64}$ They concluded that $55 \%$ of the cation exchange capacity is compensated in the Stern layer (= occupation of surface sites by cations) and $45 \%$ is compensated in the EDL. This estimation was made for an ionic strength of 0.4 M. For reasons of simplification, this value was taken for all ionic strengths in this study. A similar value was also used for the Helvetic Marl. The effect of the Stern layer was taken into account by reducing the CEC value by a factor of 0.55 . The data were remodeled using the adapted CEC for the Donnan space and a Donnan porosity $\eta_{\mathrm{D} \text {,free-Stern }}$ resulting by decreasing the Donnan porosity, $\eta_{\mathrm{D} \text {,free }}$ by the volume of the Stern layer, $\eta_{\text {Stern }}$. Unfortunately, this model adaption did not improve the fitting of the experimental data (Figure 4).

Both OPA and HM contain illite/smectite (I/S) mixed layers (Table 1). It is assumed that the smectite content in I/S mixed layers is $15-25 \% .^{32,53,65}$ Owing to this, the amount of smectite in OPA is ca. $2 \%$ and ca. $1 \%$ in HM. The volume of interlayer pore water in OPA and HM is $1.4 \mathrm{~mL} / \mathrm{kg}$ and $0.8 \mathrm{~mL} / \mathrm{kg}$, respectively (assuming that the interlayer water is present as a one-layer hydrate; ${ }^{44}$ interlayer spacing is $0.25 \mathrm{~nm}$; TOT layer is $1 \mathrm{~nm}$; water density is $1 \mathrm{~kg} / \mathrm{dm}^{3}$; specific surface area of smectite is 750 $\left.\mathrm{m}^{2} / \mathrm{g}^{66,64}\right)$. The total water in OPA is $48.8 \mathrm{~mL} / \mathrm{kg}, 3 \%$ of it being interlayer water. In $\mathrm{HM}$, the total water content is $11.3 \mathrm{~mL} / \mathrm{kg}$, $7.3 \%$ present as interlayer water. Knowing the volume of the interlayer water, the amount of charge-compensating $\mathrm{Na}$-ions in the interlayer could be calculated as 0.0083 equiv $/ \mathrm{kg}$ for OPA and 0.0039 equiv $/ \mathrm{kg}$ for HM. Taking the interlayer pore space and modified CEC into account, the modeled and measured anion exclusion are still not in agreement. As discussed in a previous section, there could be interlayer equivalent pores, which like "real" interlayer pores, are not accessible to anions. Because the amount of ILE pores can neither be estimated from the mineralogy nor from the bulk density of the samples, it is a fit parameter. However, the ILE porosity and the amount of CEC compensated in these interlayer equivalent pores were adapted in such a way that the modeled and measured anion accessible porosity were in agreement. The CEC located in the ILE of OPA is 0.0275 equiv $/ \mathrm{kg}$ and 0.016 equiv $/ \mathrm{kg}$ for HM. The ILE porosity in OPA is 0.037 , which corresponds to a relative porosity of 0.30 and 0.019 for HM, which corresponds to a relative porosity of 0.62 of the total porosity of Helvetic Marl. Helvetic Marl thus has relatively more interlayer equivalent pores than Opalinus Clay. This can be explained by a larger bulk density or larger partial clay bulk density in HM.

This study shows that a model based on a single Donnan-type porosity $^{41}$ is not able to describe the ionic strength-dependent anion porosity of natural clay rocks. Therefore, the pore space needs to be subdivided into three pore types: a permanent uncharged pore space, a permanent charged and inaccessible for anions pore space, and a Donnan pore space. Both the permanent uncharged and charged pore spaces are not affected by the ionic strength of the pore solution. Only with a reduced Donnan space is it possible to satisfactorily describe the ionic strength dependency of the anion porosity. Introducing an ILE and an uncharged porosity adds microstructural information to the Donnan approach and makes it more suitable to describe the experimental data. Unfortunately, it is not possible to estimate the fraction of ILE porosity or that of the uncharged porosity from the mineral composition of the rocks. Diffusion experiments and additional microstructural information is thus required in order to estimate both parameters.

Although it was shown that the diffusive behavior of monovalent anions such as $\mathrm{Cl}^{-}$in clay stones can be described by an adapted Donnan approach, it remains unclear whether biand trivalent anions behave in a similar way. A systematic study with polyvalent anions is thus necessary for confirming our approach. However, first diffusion measurements with $\mathrm{SO}_{4}{ }^{2-}$ and $\mathrm{SeO}_{4}{ }^{2-}$ in Opalinus Clay at a given pore water composition showed similar accessible porosity values for mono- and bivalent anions. ${ }^{68}$ A similar observation was made by Bazer-Bachi et al. ${ }^{67}$ who compared the diffusion of ${ }^{36} \mathrm{Cl}^{-}$and ${ }^{35} \mathrm{SO}_{4}{ }^{2-}$ in CallovoOxfordian illite. The charge of the diffusing species thus seems to play only a secondary role. 


\section{ASSOCIATED CONTENT}

\section{S Supporting Information}

The Supporting Information is available free of charge on the ACS Publications website at DOI: 10.1021/acs.est.6b03781.

Original data of the diffusion experiments (PDF)

\section{AUTHOR INFORMATION}

\section{Corresponding Authors}

*E-mail: cornelia.wigger@psi.ch; phone: +41 563105036.

*E-mail: luc.vanloon@psi.ch; phone: +41 563102257.

\section{ORCID}

Cornelia Wigger: 0000-0002-7635-6949

\section{Notes}

The authors declare no competing financial interest.

\section{ACKNOWLEDGMENTS}

The authors thank S. Frick and P. Bunic for assistance during the experimental work and M. Keller for the preparation of the samples. The authors also thank Christine Lemp, Martin Mazurek, and Niklaus Waber, who performed the mineralogy analysis at the University of Bern. T. Gimmi and M. Glaus are warmly thanked for the many discussions and suggestions to improve the manuscript. This study was partially financed by the Nuclear Waste Management Organization of Canada (NWMO) and the Paul Scherrer Institut (PSI).

\section{REFERENCES}

(1) Agence Nationale pour la Gestion des Dechets Radioactifs, ANDRA. Clay 2001 dossier: Progress report on feasibility studies and research into deep geological disposal of high-level, long-lived waste. Synthesis report. Andra, Paris, France, 2001.

(2) Ondraf/Niras. Technical overview of the SAFIR 2 report; NIROND 2001-05 E; ONDRAF/NIRAS:Brussels, Belgium 2001.

(3) Nagra. Projekt Opalinuston - Synthese der geowissenschaftlichen Untersuchungsergebnisse - Entsorgungsnachweis für abgebrannte Brennelemente, verglaste hochaktive sowie langlebige mittelaktive Abfälle; Nagra Technischer Bericht NTB 02-03; Nagra: Wettingen, Switzerland, 2002.

(4) NWMO. Preliminary assessment for siting a deep geological repository for Canada's used nuclear fuel; APM-REP-06144-0124; Nuclear Waste Management Organization: Toronto, Canada, 2015.

(5) Altmann, S.; Tournassat, C.; Goutelard, F.; Parneix, J.-C.; Gimmi, T.; Maes, N. Diffusion-driven transport in clayrock formations. Appl. Geochem. 2012, 27 (2), 463-478.

(6) Grolimund, D.; Wang, H.; Van Loon, L. R.; Marone, F.; Diaz, N.; Kaestner, A.; Jakob, A., Microscopic chemical imaging: A key to understand ion mobility in tight formations. In Filling the Gaps-From Microscopic Pore Structures to Transport Properties in Shales; Clay Minerals Society Workshop Lectures Series; Clay Minerals Society: Urbana, IL, 2016; Vol. 21, Chapter 9, pp 105-128.10.1346/CMS-WLS21.9

(7) Leroy, P.; Revil, A.; Altmann, S.; Tournassat, C. Modeling the composition of the pore water in a clay-rock geological formation (Callovo-Oxfordian, France). Geochim. Cosmochim. Acta 2007, 71 (5), $1087-1097$.

(8) Houben, M.; Desbois, G.; Urai, J. Pore morphology and distribution in the shaly facies of Opalinus Clay (Mont Terri, Switzerland): Insights from representative 2D BIB-SEM investigations on $\mathrm{mm}$ to $\mathrm{nm}$ scale. Appl. Clav Sci. 2013, 71, 82-97.

(9) Kuila, U.; Prasad, M. Specific surface area and pore-size distribution in clays and shales. Geophys. Prospect. 2013, 61 (2), 341-362.

(10) Sing, K. S. Reporting physisorption data for gas/solid systems with special reference to the determination of surface area and porosity (Recommendations 1984). Pure Appl. Chem. 1985, 57 (4), 603-619.
(11) Plecis, A.; Schoch, R. B.; Renaud, P. Ionic transport phenomena in nanofluidics: experimental and theoretical study of the exclusionenrichment effect on a chip. Nano Lett. 2005, 5 (6), 1147-1155.

(12) Appelo, C.; Van Loon, L.; Wersin, P. Multicomponent diffusion of a suite of tracers ( $\mathrm{HTO}, \mathrm{Cl}, \mathrm{Br}, \mathrm{I}, \mathrm{Na}, \mathrm{Sr}, \mathrm{Cs}$ ) in a single sample of Opalinus Clay. Geochim. Cosmochim. Acta 2010, 74 (4), 1201-1219.

(13) Sposito, G. The Surface Chemistry of Natural Particles; Oxford University Press: New York, 2004.

(14) Van Loon, L. R.; Soler, J. M.; Bradbury, M. H. Diffusion of HTO, ${ }^{36} \mathrm{Cl}^{-}$and ${ }^{125} \mathrm{I}^{-}$in Opalinus Clay samples from Mont Terri: Effect of confining pressure. I. Contam. Hvdrol. 2003, 61 (1-4), 73-83.

(15) Van Loon, L. R.; Mibus, J. A modified version of Archie's law to estimate effective diffusion coefficients of radionuclides in argillaceous rocks and its application in safety analysis studies. Appl. Geochem. 2015, 59, 85-94.

(16) Bolt, G. H.; de Haan, F. A. M. Anion Exclusion in Soil. In Developments in Soil Science; Bolt, G. H., Ed.; Elsevier: Amsterdam, 1979; Vol. 5, Part B, Chapter 7, pp 233-257.

(17) Muurinen, A. Diffusion of anions and cations in compacted sodium bentonite. Eng. Geol. 1990, 28, 359.

(18) Van Loon, L. R.; Soler, J. M.; Jakob, A.; Bradbury, M. H. Effect of confining pressure on the diffusion of $\mathrm{HTO},{ }^{36} \mathrm{Cl}^{-}$and ${ }^{125} \mathrm{I}^{-}$in a layered argillaceous rock (Opalinus Clay): diffusion perpendicular to the fabric. Appl. Geochem. 2003, 18 (10), 1653-1662.

(19) Descostes, M.; Blin, V.; Bazer-Bachi, F.; Meier, P.; Grenut, B.; Radwan, J.; Schlegel, M. L.; Buschaert, S.; Coelho, D.; Tevissen, E. Diffusion of anionic species in Callovo-Oxfordian argillites and Oxfordian limestones (Meuse/Haute-Marne, France). Appl. Geochem. 2008, 23 (4), 655-677.

(20) Pearson, F. What is the porosity of a mudrock?; Geological Society: London, 1999; Special Publications, Vol. 158, pp 9-21.

(21) Liu, C.; Zachara, J. M.; Felmy, A.; Gorby, Y. An electrodynamicsbased model for ion diffusion in microbial polysaccharides. Colloids Surf. B 2004, 38 (1), 55-65.

(22) Appelt, H.; Holtzclaw, K.; Pratt, P. Effect of anion exclusion on the movement of chloride through soils. Soil Science Society of America Iournal 1975, 39 (2), 264-267.

(23) Smith, D.; Pivonka, P.; Jungnickel, C.; Fityus, S. Theoretical analysis of anion exclusion and diffusive transport through platy-clay soils. Transp. Porous Media 2004, 57 (3), 251-277.

(24) Schofield, R. K. Calculation of surface areas from measurements of negative adsorption. Nature 1947, 160 (4064), 408.

(25) Glaus, M. A.; Frick, S.; Rossé, R.; Van Loon, L. R. Comparative study of tracer diffusion of HTO, ${ }^{22} \mathrm{Na}^{+}$and ${ }^{36} \mathrm{Cl}^{-}$in compacted kaolinite, illite and montmorillonite. Geochim. Cosmochim. Acta 2010, 74 (7), 1999-2010.

(26) Aertsens, M.; Wemaere, I.; Wouters, L. Spatial variability of transport parameters in the Boom Clay. Appl. Clav Sci. 2004, 26 (1), 37-45.

(27) Frasca, B.; Savoye, S.; Wittebroodt, C.; Leupin, O.; Descostes, M.; Grenut, B.; Etep-Batanken, J.; Michelot, J.-L. Influence of redox conditions on iodide migration through a deep clay formation (Toarcian argillaceous rock, Tournemire, France). Appl. Geochem. 2012, 27 (12), 2453-2462.

(28) Van Loon, L. R.; Glaus, M. A.; Müller, W. Anion exclusion effects in compacted bentonites: towards a better understanding of anion diffusion. Appl. Geochem. 2007, 22 (11), 2536-2552.

(29) Tian, W.; Li, C.; Liu, X.; Wang, L.; Zheng, Z.; Wang, X.; Liu, C. The effect of ionic strength on the diffusion of ${ }^{125} \mathrm{I}$ in Gaomiaozi bentonite. I. Radioanal. Nucl. Chem. 2013, 295 (2), 1423-1430.

(30) Shackelford, C. D.; Daniel, D. E. Diffusion in saturated soil. II: Results for compacted clay. I. Geotech. Eng. 1991, 117 (3), 485-506.

(31) Wersin, P.; Soler, J.; Van Loon, L.; Eikenberg, J.; Baeyens, B.; Grolimund, D.; Gimmi, T.; Dewonck, S. Diffusion of HTO, $\mathrm{Br}^{-}, \mathrm{I}^{-}, \mathrm{Cs}^{+}$, ${ }^{85} \mathrm{Sr}^{2+}$ and ${ }^{60} \mathrm{Co}^{2+}$ in a clay formation: results and modelling from an in situ experiment in Opalinus Clay. Appl. Geochem. 2008, 23 (4), 678691.

(32) Wersin, P.; Mazurek, M.; Waber, H.; Mäder, U.; Gimmi, T.; Rufer, D.; De Haller, A. Rock and porewater characterisation on drillcores from 
the Schlattingen borehole; Arbeitsbericht NAB 12-54; Nagra: Wettingen, Switzerland, 2013

(33) Mäder, U. Reference pore water for the Helvetic marls for the provisional safety-analysis in the framework of sectoral plan; interim results (SGT-ZE); Arbeitsbericht NAB 09-15; Nagra: Wettingen, Switzerland, 2010.

(34) Bazer-Bachi, F.; Tevissen, E.; Descostes, M.; Grenut, B.; Meier, P.; Simonnot, M.-O.; Sardin, M. Characterization of iodide retention on Callovo-Oxfordian argillites and its influence on iodide migration. Physics and Chemistry of the Earth, Parts A/B/C 2006, 31 (10), 517-522.

(35) Moors, $\mathrm{H}$. Topical report on the effect of the ionic strength on the diffusion accessible porosity of Boom Clay; SCK.CEN-ER-02; SCK. CEN: Mol, Belgium, 2005.

(36) Mazurek, M.; Alt-Epping, P.; Bath, A.; Gimmi, T.; Waber, H. N.; Buschaert, S.; De Cannière, P.; De Craen, M.; Gautschi, A.; Savoye, S.; et al. Natural tracer profiles across argillaceous formations. Appl. Geochem. 2011, 26 (7), 1035-1064.

(37) Wittebroodt, C.; Savoye, S.; Frasca, B.; Gouze, P.; Michelot, J.-L. Diffusion of $\mathrm{HTO},{ }^{36} \mathrm{Cl}^{-}$and ${ }^{125} \mathrm{I}^{-}$in Upper Toarcian argillite samples from Tournemire: Effects of initial iodide concentration and ionic strength. Appl. Geochem. 2012, 27 (7), 1432-1441.

(38) Ishidera, T.; Miyamoto, S.; Sato, H. Effect of sodium nitrate on the diffusion of $\mathrm{Cl}^{-}$and $\mathrm{I}^{-}$in compacted bentonite. I. Nucl. Sci. Technol. 2008, 45 (7), 610-616.

(39) Van Loon, L. Effective diffusion coefficients and porosity values for argillaceous rocks and bentonite: Measured and estimated values for the provisional safety analyses for SGT-E2; National Cooperative for the Disposal of Radioactive Waste: Wettingen, Switzerland, 2014.

(40) Muurinen, A.; Karnland, O.; Lehikoinen, J. Effect of homogenization on the microstructure and exclusion of chloride in compacted bentonite. Physics and Chemistry of the Earth, Parts $A / B / C$ 2007, 32 (1), 485-490.

(41) Birgersson, M.; Karnland, O. Ion equilibrium between montmorillonite interlayer space and an external solution-consequences for diffusional transport. Geochim. Cosmochim. Acta 2009, 73 (7), $1908-1923$

(42) Appelo, C. A. J.; Wersin, P. Multicomponent diffusion modeling in clay systems with application to the diffusion of tritium, iodide, and sodium in opalinus clay. Environ. Sci. Technol. 2007, 41 (14), 50025007.

(43) Jougnot, D.; Revil, A.; Leroy, P. Diffusion of ionic tracers in the Callovo-Oxfordian clay-rock using the Donnan equilibrium model and the formation factor. Geochim. Cosmochim. Acta 2009, 73 (10), 27122726.

(44) Bourg, I. C.; Sposito, G.; Bourg, A. C. M. Modeling the diffusion of $\mathrm{Na}+$ in compacted water-saturated $\mathrm{Na}$-bentonite as a function of pore water ionic strength. Appl. Geochem. 2008, 23 (12), 3635-3641.

(45) Tournassat, C.; Chapron, Y.; Leroy, P.; Bizi, M.; Boulahya, F. Comparison of molecular dynamics simulations with triple layer and modified Gouy-Chapman models in a $0.1 \mathrm{M} \mathrm{NaCl}^{-}$montmorillonite system. I. Colloid Interface Sci. 2009, 339 (2), 533-541.

(46) Greathouse, J. A.; Feller, S. E.; McQuarrie, D. A. The modified Gouy-Chapman theory: comparisons between electrical double layer models of clay swelling. Langmuir 1994, 10 (7), 2125-2130.

(47) Tournassat, C.; Appelo, C. A. J. Modelling approaches for anionexclusion in compacted Na-bentonite. Geochim. Cosmochim. Acta 2011, 75 (13), 3698-3710.

(48) Chagneau, A. 1.; Tournassat, C.; Steefel, C. I.; Bourg, I. C.; Gaboreau, S. p.; Esteve, I. n.; Kupcik, T.; Claret, F.; Schäfer, T. Complete Restriction of ${ }^{36} \mathrm{Cl}^{-}$Diffusion by Celestite Precipitation in Densely Compacted Illite. Environ. Sci. Technol. Lett. 2015, 2 (5), 139-143.

(49) Tournassat, C.; Bourg, I. C.; Holmboe, M.; Sposito, G.; Steefel, C. I. Molecular dynamics simulations of anion exclusion in clay interlayer nanopores. Clavs and Clav Minerals 2016, 64 (4), 374-388.

(50) Nagra. Vorschlag geologischer Standortgebiete für das SMA- und das HAA-Lager: Geologische Grundlagen; Nagra Technischer Bericht NTB 08-04; Nagra: Wettingen, Switzerland, 2008.

(51) Nagra. Etappe 2: Vorschlag weiter zu untersuchender geologischer Standortgebiete mit zugehörigen Standortarealen für die
Oberflächenanlage. Geologische Grundlagen. Nagra Technol. Ber. 1402; Nagra: Wettingen, Switzerland, 2014.

(52) Baeyens, B.; Bradbury, M. H. Cation exchange capacity measurements on Illite using the sodium and cesium isotope dilution technique: effects of the index cation, electrolyte concentration and competition: modeling. Clavs Clav Miner. 2004, 52 (4), 421-431.

(53) Brindley, G. W.; Brown, G. Crystal Structures of Clav Minerals and Their X-rav Identification; Mineralogical Society: London, 1980.

(54) Norrish, K. The swelling of montmorillonite. Discuss. Faradav Soc. 1954, 18, 120-134.

(55) Kozaki, T.; Liu, J.; Sato, S. Diffusion mechanism of sodium ions in compacted montmorillonite under different $\mathrm{NaCl}$ concentration. Physics and Chemistry of the Earth, Parts A/B/C 2008, 33 (14), 957-961.

(56) Ozbek, H. Viscosity of Aqueous Sodium Chloride Solutions from 0$150^{\circ} \mathrm{C}$; Lawrence Berkeley National Laboratory: 2010.

(57) Appelo, C.; Postma, D. Geochemistry, Groundwater and Pollution; Balkema: Rotterdam 2005; p 536.

(58) Wersin, P.; Mazurek, M.; Mäder, U. K.; Gimmi, T.; Rufer, D.; Lerouge, C.; Traber, D. Constraining porewater chemistry in a $250 \mathrm{~m}$ thick argillaceous rock sequence. Chem. Geol. 2016, 434, 43-61.

(59) Tournassat, C.; Gaboreau, S.; Robinet, J.-C.; Bourg, I. C.; Steefel, C. I. Impact of microstructure on anion exclusion in compacted clay media. In Filling the Gaps-From Microscopic Pore Structures to Transport Properties in Shales; Clay Minerals Society Workshop Lectures Series; Clay Minerals Society: Urbana, IL, 2016; Vol. 21, pp 137-149.10.1346/ CMS-WLS-21.11

(60) Deer, W. A.; Howie, R. A.; Zussman, J. An Introduction to the RockForming Minerals. Longman: London, 1992; Vol. 696.

(61) Edwards, D.; Posner, A.; Quirk, J. Repulsion of chloride ions by negatively charged clay surfaces. Part 2.-monovalent cation montmorillonites. Trans. Faradav Soc. 1965, 61, 2816-2819.

(62) Sposito, G. The Diffuse-Ion Swarm near Smectite Particles Suspended in 1:1 Electrolyte Solutions: Modified Gouy-Chapman Theory and Quasicrystal Formation. In Clav-Water Interface and Its Rheological Implications; Clay Minerals Society: Boulder, CO, 1992; Vol. 4, pp 128-152.

(63) Donnan, F.; Guggenheim, E. Exact thermodynamics of membrane equilibrium. Z. Phvs. Chem. A 1932, 162, 346-360.

(64) Appelo, C. A. J.; Van Loon, L. R.; Wersin, P. Multicomponent diffusion of a suite of tracers ( $\mathrm{HTO}, \mathrm{Cl}, \mathrm{Br}, \mathrm{I}, \mathrm{Na}, \mathrm{Sr}, \mathrm{Cs}$ ) in a single sample of Opalinus Clay. Geochim. Cosmochim. Acta 2010, 74 (4), $1201-1219$.

(65) Pearson, F.; Arcos, D.; Bath, A.; Boisson, J.; Fernandez, A.; Gaebler, H.; Gaucher, E.; Gautschi, A.; Griffault, L.; Hernan, P. Geochimistry of water in the Opalinus Clay formation at the Mont Terri Rock Laboratory-Synthesis Report. Reports of the Federal Office for Water and Geology (FOWG), Geology Series (5).

(66) Pitteloud, C.; Powell, D. H.; Soper, A. K.; Benmore, C. J. The structure of interlayer water in Wyoming montmorillonite studied by neutron diffraction with isotopic substitution. Phvs. B 2000, 276, 236237.

(67) Bazer-Bachi, F.; Descostes, M.; Tevissen, E.; Meier, P.; Grenut, B.; Simonnot, M.-O.; Sardin, M. Characterization of sulphate sorption on Callovo-Oxfordian argillites by batch, column and through-diffusion experiments. Physics and Chemistry of the Earth, Parts A/B/C 2007, 32 (8), 552-558

(68) Van Loon, L. R. Diffusion of $\mathrm{SO}_{4}{ }^{2-}$ and $\mathrm{SeO}_{4}{ }^{2-}$ in Opalinus Clay. Unpublished results. 